\title{
Subrogation of the Guarantee Fund and liability of the persons failing to take out mandatory insurance: an endorsement of the prevailing opinion of Portuguese courts
}

The paper discusses the problem of subrogation of the Guarantee Fund, especially in a case when a person who failed to take out the third-party liability motor insurance was not liable for the accident. The author presents current trends in Portuguese case-law on this matter and examines whether the Guarantee Fund should be entitled to claim the redress.

Keywords: subrogation, Guarantee Fund, third-party liability motor insurance

\section{Introduction}

Ms. Mole Juliana was the owner of a vehicle that she had not formally withdrawn from use, but that she did not use or intend to use and kept parked in the yard of her house ${ }^{1}$. As a consequence, she did not take out civil liability insurance in its regard. In November 2006, her son took the vehicle without her knowledge or consent and was involved in a road traffic accident, causing the death of all the passengers of the vehicle.

As no liability insurance had been taken out, compensation to the victims was paid by the Portuguese compensation body ("Fundo de Garantia Automóvel" - Automobile Guarantee Fund), which then claimed redress from the driver's estate and from the owner of the vehicle.

The owner submitted in her defence that she had no obligation to take out insurance. The first instance Court rejected her argument; but the appellate Court to whom she recurred upheld it.

1. Main abbreviations: Art.: article; Rap.: Judge Rapporteur. All the Portuguese case law mentioned is available (in Portuguese) at www.dgsi.pt. 
The Automobile Guarantee Fund finally brought the case to the Portuguese Supreme Court, which found the decision to rely on two interrelated questions ${ }^{2}$. Namely, whether the owner of the vehicle had the duty to take out insurance, and, if so, whether the fact that she had not fulfilled her duty was enough to allow the Fund to claim redress from her, although she was not liable for the accident. Both of them raised doubts, however, as to how the norms of the First and Second Motor Insurance Directives (which were in force at the time of the accident) should be construed and prompted the Supreme Court to refer to the ECJ for a preliminary ruling.

The first question asked whether Art. 3[1) of the First Motor Insurance Directive should be interpreted as meaning that the conclusion of an insurance contract against civil liability in relation to the use of a motor vehicle is obligatory when the vehicle concerned is parked on private land, solely by the choice of the owner, who no longer intends to drive the vehicle. The ECJ replied affirmatively. According to the court, a vehicle which is registered and therefore has not been officially withdrawn from use, and which is capable of being driven, corresponds to the concept of 'vehicle' within the meaning of Art. 1(1) of the First Directive. The intention of its owner is irrelevant for that concept; and this understanding fosters the protection of the victims of road traffic accidents.

The second question regarded whether Art. 1(4) of the Second Motor Insurance Directive should be interpreted as precluding national legislation which provides that the compensation body has the right to bring an action against the person under the obligation to take out insurance even if that person was not liable for the accident ${ }^{3}$. The answer was negative. According to the court, European legislation does not intend to harmonize the various matters relating to the actions brought by such a body, in particular the determination of the other persons against whom such actions might be brought. Those matters fall within the scope of the national law of each Member State.

From the standpoint of the construction of the harmonized EU law, the answer given to the first question would no doubt stand out. It continues the path trodden by decisions such as Candolin and Others (C-537/03, of 30th June 2005) Farrell (C-356/05, of 19th April 2007) or Vnuk (C$162 / 13$, of 28th November 2017), bringing harmonized law increasingly to express the purpose of protecting the victims of road traffic accidents. One can say that it matched what was expected. As the Supreme Court points out, in the light of the protection of the victims, it is irrelevant how the driver got access to the vehicle - that same idea underlies the extension of coverage to cases (such as those of theft) where damage is caused by persons who do not have express or implied authorization to drive the vehicle (Art. $8^{\circ}{ }^{\circ}$, No. 2 of the former Motor Insurance Act; see also Art.

2. The final decision on the case was adopted by the judgement of the Supreme Court of Justice $8^{\text {th }}$ November 2018 (Rap. Abrantes Geraldes), Proc. 770/12.3TBSXL.L1.S1.

3. The question was rephrased for the sake of clarity. In its original version, it went as "Article 1(4) of Second Council Directive 84/5/EEC of $30^{\text {th }}$ December 1983 on the approximation of the laws of the Member States relating to insurance against civil liability in respect of the use of motor vehicles, as amended by Directive 2005/14/EC of the European Parliament and of the Council of $11^{\text {th }}$ May 2005, must be interpreted as not precluding national legislation which provides that the body referred to in that provision has the right to bring an action, in addition to an action against the person or persons responsible for the accident, against the person who was subject to the obligation to take out insurance against civil liability in respect of the use of the vehicle which caused the damage or injuries for which compensation was provided by that body, but who had not concluded a contract for that purpose, even if that person has no civil liability for the accident in which the damage or injuries occurred." 
Subrogation of the Guarantee Fund and liability of the persons failing to take out mandatory...

13. ${ }^{\circ}$, No. 1, a) of the present Motor Insurance Directive, which was, though, not in force at the time of the accident ). Therefore, as long as the car poses the risk of its being used, insurance should be taken out in its regard.

From that same standpoint, the decision regarding the second question would not rise particular interest. The ECJ considers that, although EU law enables the member states to regulate the settlement of claims brought by the compensation body against those liable for the accident, it leaves it to competence of the member states to determine if the compensation body can bring an action against any other persons. Consequently, the ECJ steps back and recognizes that the member States are both competent to set out this right, and free in regard of how they do it.

However, the question that the ECJ does not have to delve into is no doubt the thorniest from the perspective of the internal law. There lies, in the words of the Supreme Court, the Gordian knot of its decision. Shortly phrased, it goes as follows: can the compensation body which paid compensation to the victim claim redress from the person who, having the duty to do so, failed to take out insurance, even though he/she was not liable for the accident? It came to my knowledge that it has also raised controversy in Poland; it shall not come as a surprise if it does so elsewhere.

It is that same question that this article will try to answer, giving account of the different stances of case law and scholarship in its regard, of the issues raised by the change in the norms on compulsory motor insurance that meanwhile occurred, and of broader points that should be made against any of the backgrounds. Although the discussion will be framed by Portuguese statutes and case law, the arguments summoned will be mainly material and functional, rather than formalistic. As the Supreme Court points out in the final decision of the case that led to the preliminary ruling, formal arguments are not conclusive or decisive in this matter. It is my hope that it can contribute to the dialogue between legal systems facing similar issues.

\section{The former statutes, the new statutes and the arguments for an autonomous ground of liability towards the Fund}

\section{The first approach to the problem}

The facts of the case took place when the former Act on motor insurance was still in force. The former Act was replaced in 2007 by the present Motor Insurance Act, which has been in force since the $21^{\text {st }}$ October $2007^{4}$. Many of the provisions which are of interest to the problem under scrutiny have remained essentially the same. Not so, though, the provision concerning sub-subrogation of the Fund. That provision shall therefore be singled out for each of the Acts, whereas the other points of regime will be handled simultaneously for both.

The provision that set out the rights of redress of the fund was Art. $25 .^{\circ}$, which bore the title "Subrogation of the Fund" and can be translated as follows.

"1 - Once compensation is paid, the Motor Guarantee Fund will be subrogated to the rights of the victim and it shall further be entitled to interest on delay and to the reimbursement of the expenses incurred with settlement and recovery.

4. It approved by Law Decree No. 522/85, of 31 December 1985, that had already undergone many changes since its inception; the former Act was approved by Law-Decree no. 291/2007, of 21 August 2007. 
2 - In the event of insolvency [of the insurance company], the Motor Guarantee Fund will only have the right to take action against the insolvent insurance company.

3 - Those who, having the duty to take out insurance, have failed to do so, shall respond before the Motor Guarantee Fund as set out in No. 1 and will in return have a right of recourse against other persons liable for the accident in what regards the amounts paid."

As the Supreme Court points out, there was controversy in the case law as to whether the Fund could bring an action against those who, having failed to take out insurance, were not liable for the accident. In order to follow the discussion, it will be necessary to identify, according to the Portuguese law, those who may be liable for a motor traffic accident, those who have the duty to take out motor insurance, and those who are covered by the insurance contract. Finally, the cases where the Fund can be brought to compensate the victims should be laid out.

\section{Liability for road traffic accidents, duty to take out insurance, scope of coverage and cases where the Fund is brought to compensate}

In order to understand who can be held liable for road traffic accidents, one has to look into the norms of the Civil Code.

Under the Civil Code, the general rule is that there is only liability based on fault; strict liability only exists where specifically set out (Art. $483 .^{\circ}$ ). Liability based on fault will tend to strike the driver of the vehicle, who may be the owner or not ${ }^{5}-6$.

However, the Code does set out a case of case of strict liability for damage caused by those risks which are characteristic of the use of a vehicle (Art. 503. ${ }^{\circ}$, No. 1$)^{\text {? }}$. Those risks may relate to human failure (vg., a seizure of the driver), machine failure, or defects of the $\mathrm{road}^{8}$. The person responsible for them is identified by two requirements: the de facto control of the vehicle, termed as "direção efetiva" and the use of the vehicle in one's own interest.

"Direção efetiva" refers exactly to the de facto control of the vehicle, which is independent of having a legal title to the vehicle: it belongs to the person who is in condition both to take advantage from the vehicle and to control and inspect its functioning ${ }^{9}$. To use the vehicle in one's own interest does not require that use to be direct. There can be a personal interest in having

5. One could also attribute fault for the accident to the holder of the vehicle who, though not having caused the accident through his own driving, chose an inept driver, or failed to keep the vehicle in line with the legal safety requirements. However, case law does not seem to reason in those terms. It considers the fault of the holder for the purposes of contributory negligence, whereas, when the victim is a third party, the liability of the holder who was not driving seems to be framed systematically as a strict liability.

6. Under Art. $503 .^{\circ}$, No. 3, presumption of fault applies in case the driver is a person driving in the economic interest of someone else (maxime, an employee).

7. The provision can be translated as follows: "The person that has de facto control ["direcção efectiva") over a vehicle and uses it in his/her own interest, directly or through an agent, shall be liable for the risks that are characteristic of the vehicle, even if it is not being used in road traffic ".

8. Alarcão, R. de, Ribeiro, J. de Sousa, Monteiro, J. F. Sinde, Sá, Almeno de, Proença, J. C. Brandão, Direito das obrigações, s. ed., Coimbra, 1983, Varela, J. de M. Antunes, Das obrigações em geral, I, Almedina, Coimbra, 2000, p. 268.

9. Alarcão, R., et al., Direito..., pp. 262-263; , p. 657. 
Subrogation of the Guarantee Fund and liability of the persons failing to take out mandatory...

somebody else use the vehicle, be it an economic interest - vg., in case of use by an employee ${ }^{10}-$ or a moral interest - vg., in case one lends the vehicle to a son or friend. The sufficiency of a moral interest is deemed to foster care in the choice of the person one lends a vehicle $t^{11}$. The person driving in the economic interest of another - the employee - is deemed not to have a personal interest in using the car.

These two qualities identify the person that creates the special risks entailed by the use of vehicles and should therefore respond for them. He/she is generically referred to as the holder of the vehicle - in a similar sense to that of "Halter "or "guardien"12.

There can be more than one holder of the same vehicle. Normally, the owner tends to qualify as holder: he/she will be the one who drives it, or who allows someone else to drive it in his/her interest.

Now, if the owner gives the other person the right to use the vehicle, this other person will acquire the de facto power that identifies "direcção efectiva". That may occur as a consequence of several different contracts - concession of usufruct, sale with retention of title, leasing, rental, lending, (...). In any of these cases, the person that receives control over the car will also use it in his/her own interest. The new person entitled to use the vehicle will then become its holder. If by giving him/her that right the owner loses his/her actual control over the state of the vehicle, then the new user will become the sole holder of the vehicle and the only one liable for its risks. This will tend to happen in medium/long term contracts. If, though, the owner retains the power to inspect and repair the vehicle (vg., in the cases he/she lends it to a friend for a relatively short period) he/she will not lose "direç̧ão efectiva". In those cases, there will be two (or more) holders of the vehicle, who will answer solidarily for strict liability.

So far, we have handled cases of authorized use of the vehicle. However, the vehicle may also be taken without consent of its legitimate holder - for instance, in case of robbery or theft of the vehicle, or merely temporary non authorized use of it. If the vehicle is taken, its unlawful user will gain control over the vehicle and pursue his/her interests with its use. He/she will become the holder of the vehicle. On his/her turn, the former legitimate user of the vehicle will lose control over it; he/ she still retains that control, nonetheless, for a certain amount of time (his/her checks and repairs remain effective for a while), and therefore does not lose immediately "direç̧ão efectiva". He/she will not, however, have any interest in the non-authorized use of the vehicle. Therefore, he/she loses the quality of holder of the vehicle; the person illegitimately using the vehicle becomes its only holder ${ }^{13}$.

Summing up, one can conclude that the person whose vehicle was taken without consent is not responsible before the victims under the rules on strict liability for the use of vehicles. It should be added that there is no acknowledgment of a duty towards potential victims to take precautions in order to prevent a vehicle from being unlawfully taken; therefore, the person who

10. In case there is fault from the employee driving the car, the employer is also responsible under another ground for strict liability, referring to the duty to answer for torts committed by a subordinate (Art. $500{ }^{\circ}$ Civil Code).

11. Alarcão, R., et al., Direito..., p. 263; Varela, J. de M. Antunes, Das obrigações..., I, p. 665; Matos, F. de Albuquerque, Os proprietários e condutores de veículos à luz do binómio direcção efectiva e interesse próprio (Anotação), "Cadernos de Direito Privado", 2014, n. ${ }^{\circ}$ 47, pp. 48-49.

12. Varela, J. de M. Antunes, Das obrigações..., I, p. 657. Costa, M. J. de Almeida, Direito das obrigações, Almedina, Coimbra, 2009, pp. 629-630. On what is said next, see also Alarcão, R., et al., Direito..., pp. 263-264; Matos, F. de Albuquerque, Os proprietários..., pp. 48-51 and 54 .

13. Silva, J. Calvão da, Acordão do Supremo Tribunal de Justiça de 13 de Fevereiro de 2003, Anotação, „RLJ”, 2001, n. ${ }^{0} 3922$, p. 201. Matos, F. de Albuquerque, Os proprietários..., p. 49. 
was dispossessed is also not held responsible for having negligently caused the accident ${ }^{14}$. He/ she may eventually be brought to answer under the rules on strict liability for acts of subordinates $\left(500 .^{\circ}\right)$, when the vehicle is used by one of his/her subordinates, against his/her instructions, but still within the scope of the subordinate's functions, conceived in very broad terms. That is, however, a rather specific case.

The one unlawfully using the vehicle becomes, on its turn, its only holder and the one liable for any accident that may occur. If the accident is caused by a defective vehicle, there may be also, of course, as in any case, responsibility of the producer.

Against this background, the courts usually start from the presumption that the owner is the holder of the vehicle. It is up to him/her to rebuke that presumption, by showing that he lost control over the state of the vehicle, by granting its use to someone else, or that he/she had no interest in the use that led to the accident, since he/she had not consented in it ${ }^{15}$. Some scholarship underscores that fact of being the driver of the vehicle (even if not its owner) should also entail a presumption of holdership - which the driver can rebuke by showing that he was driving in the interest of another person, as a mere employee ${ }^{16}$. Holdership would thus be presumed in respect of two different persons.

In what regards the duty to take out liability insurance, one has to consider the norms of the Motor Insurance Act. The present Act keeps the rules that were already set out by the former one, laying out as a general rule that the duty falls upon the owner of the vehicle, except in cases of usufruct, sale with retention of title, or leasing, where the duty falls respectively upon the usufructuary, the buyer and the lessee (Art. $6 .^{\circ}$, No. 1 , present Act, and Art. $2 .^{\circ}$, No. 1 of the former Act) ${ }^{1 ?}$.

The insurance taken will, however, cover more than the liability of its policyholder: it will also cover liability both of the persons authorized to use the vehicle by the policyholder and of those that used it without consent (Art. $15 .^{\circ}$ of the present Act and Art. 8. ${ }^{\circ}$ of the former Act). That explains why, among those obliged to purchase coverage, it suffices that one of them takes out the contract - for instance, if the owner already took out insurance, the usufructuary does not have to do the same (Art. 6. ${ }^{\circ}$, No. 2, present Act., and Art. 2. ${ }^{\circ}$, No. 2, former Act). Damage arising from an accident caused by any of them would be included in the coverage.

The rationale behind these long existing norms becomes now relatively easy to grasp. The law places the duty to take out insurance upon the person who will most likely remain, during a long period of time, the one responsible for damage caused by the vehicle. That person is first of all and in line with the presumption established by the courts, the owner of the vehicle. However, in cases of long-term concession of its use, as happens with usufruct, leasing or sale with retention of title,

14. Varela, J. de M. Antunes, Das obrigações..., I, p. 664.

15. See, for instance, the judgement of the Supreme Court of Justice, of 29th January 2014 (Rap. Azevedo Ramos), Proc. No. 249/04.PTB0BR.C1.S1, or the judgement of the Supreme Court of Justice, of Gth June 2019 (Rap. Pizarro Beleza), Proc. No. 519/14.6TBEVR.E1.S1. In scholarship, Varela, J. de M. Antunes, Das obrigações..., I, p. 656.

16. Matos, F. de Albuquerque, Os proprietários..., p. 55.

17. There are special rules obliging those who in the course of their professional activities have to drive different vehicles (vg., because they repair, build, keep or test vehicles professionally) to take out liability insurance specifically in that regard (Articles 6. ${ }^{\circ}$, No. 3, and 7. ${ }^{\circ}$ of the present Act and Article 2. ${ }^{\circ}$, No. 2 of the former Act). There are also special rules regarding sports competitions (Art. 6. ${ }^{\circ}$, No. 3 , and $8 . .^{\circ}$ of the present Act and Art. $9 .{ }^{\circ}$ of the former Act). 
Subrogation of the Guarantee Fund and liability of the persons failing to take out mandatory...

it can be assumed that general control over the vehicle will be handed over to the user. He/she will tend to be the only holder of the vehicle, and should also, according to the law, be responsible for the acquisition of coverage in its regard.

All in all, the duty to take out insurance tends to overlap with the duty to indemnify. But that may not be the case - it suffices to think of the owner that lends the car to a friend for one year, and hence loses "direcção efectiva", or of the cases where the vehicle is used without consent. Both the borrower and the thief are deemed holders and will be liable for damage; but they are not under a duty to take out insurance. The damage they may cause is nonetheless covered by the contract taken out by the owner.

On its turn, the Fund can be brought to compensate the victims of the accident when the person causing it has not been identified; when, even though a responsible party has been identified, its use of the vehicle was not covered by a valid and effective insurance contract; or, lastly, in cases of insolvency of the insurance company (Art. 21. ${ }^{\circ}$, No. 2, of the former Act and Art. $49 .^{\circ}$ of the new Act $]^{18}$. In the first two cases, it is not possible for the victims to bring the claim before an insurer. In the last case, though possible, that claim would be ineffective.

\section{The right of the Fund as a right against the person failing to take out insurance, regardless of his/her liability for the accident}

Now one can turn back to the provision on the right to subrogate, that is, former Art. 54. No. 1 subrogates the Fund that has paid compensation to the rights of the victim. As the victim only has rights against those responsible for the accident, that would imply that the Fund could only bring an action against them.

However, No. 3 of the same article, instead of simply identifying the addressees of that right as those liable for the accident, also refers to those who did not comply with their duty to take out insurance. As these two groups do not overlap, that would imply that the Fund can exert its rights even against persons that were not liable for the accident. This has been the reasoning of some higher courts ${ }^{19}$. Such a right of the Fund would not lack a ground, since it is the failure to comply

18. Both the former Act and the present Act move along these general lines. The main difference between them, which is not of interest to the matter in discussion in this text, has to do with the extension and kind of damages which the Fund compensates when the person responsible has not been identified. There has always been a considerable fear of fraudulent claims in regard of material damages in these cases, which explained a very restrictive approach from the former Act towards them. The new Act has allowed for compensation of material damage even in these instances, when additional requirements, which signal the seriousness of the claim, are met (Matos, F. de Albuquerque, 0 Fundo de Garantia Automóvel, Um organismo com uma vocação eminentemente social, [in:] Estudos dedicados ao Professor Doutor Luís Alberto de Carvalho Fernandes, I, Universidade Católica Editora, Lisboa, 2011, pp. 567 and ff].

19. Dissenting opinion from Justice Afonso de Melo, on the judgement of the Supreme Court of $2^{\text {nd }}$ March 2004 (Rap. Nuno Cameira), Proc. No. 03A3499; judgement of the Appellate Court of Coimbra, $25^{\text {th }}$ May 2004 (Rap. Garcia Calejo), Proc. No. 1474/04; judgement of the Appellate Court of Lisboa, $18^{\text {th }}$ February 2014 (Rap. Ramos de Sousa), Proc. No. 8107/05.1TBSXL.L1-1; the judgement of the Appellate Court of Porto, $26^{\text {th }}$ January 2009 (Rap. Luna de Carvalho), Proc. No. 0857168, is also pointed out as part of this case law (see the Judgement of the Appellate Court of Porto, $27^{\text {th }}$ June 2018, mentioned below). However, the reasoning of the Court is far 
with the duty to take out insurance that, at least upon the first analysis, causes it to compensate the victims and therefore brings it a pecuniary loss. In fact, in what regards the establishment of causation, Portuguese courts and scholarship tend to endorse the application of three cumulative tests: condictio sine qua non, adequacy and whether the norm that was breached had as its purpose to protect against the damage at stake ("scope of the norm" test). At least the condictio and the adequacy tests would be fulfilled in regard of the damage caused to the Fund.

In order to avoid redundancies, it is useful to turn to the new provision setting out the right of the Fund before assessing the value of the arguments laid out by the courts.

The new Act keeps the privilege of the Fund, the title of the Article ("Subrogation of the Fund") and part of its provisions; but it also enlarges the regulation and recasts on several aspects.

The relevant provisions are now in Art. 54. ${ }^{\circ}$, which can be translated as follows.

1 - Once the compensation is paid, the Motor Guarantee Fund will be subrogated to the rights of the victim and it shall further be entitled to interest on delay and to the reimbursement of the expenses incurred in connection with the establishment of the facts, settlement and compensation in regard of the accident.

2 - In the event of insolvency [of the insurance company], the Motor Guarantee Fund will only have right to take action against the insolvent insurance company.

3 - The owner, the holder and the driver of the vehicle that caused the accident shall be solidarily liable for the payment to the Motor Guarantee Fund, as set out in No. 1.

4 - Those who have contributed to the mistake or defect causing the contract to be absolutely or relatively null ${ }^{20}$, as well as the seller of the vehicle that did not comply with the formalities regarding motor insurance, shall be subsidiarily responsible towards the Fund, for the payment set out in No. 1.

5 - Those who have reimbursed the Motor Guarantee Fund under No. 3 or No. 4 shall have the right of recourse against other persons liable, if there are any, in what regards the amounts they have paid.

6 - Art. $498 .^{\circ}$, n. $^{0} 2$, of the Civil Code, is applicable to the rights of the Fund as set out in the previous numbers; in case of payment to several victims, or of payments made in instalments to the same victim, the relevant date shall be that of the last payment made by the Motor Guarantee Fund.

from clear in this regard, since it considers that the person that did not take out insurance is responsible before the victim and that he/she can be exonerated before the Fund once he/she proves that the vehicle was being used abusively or anyway not in his/her interest. This reasoning does not seem compatible with seeing the duty to answer before the Fund as based solely in non-compliance of the duty to take out the contract; in this case, it seems that the Court is (though not very clearly) relying on a presumption of liability for the accident from those under the duty to take out insurance.

20. Portuguese law distinguishes between two kinds of invalidities: "nulidade", the most severe kind, which was translated as absolute nullity and "anulabilidade", which was translated as relative nullity. Both kinds of invalidity determine the retroactive elimination of the effects of the contract. However, whereas absolute nullity can be invoked at any time and by any interested party, and can be declared ex officio by the judge (Art. $286 .^{\circ}$ of the Civil Code] "relative nullity" can only be invoked by the affected party and within the time limit of one year starting from the moment when the ground for invalidity ceased to exist (Art. 287. ${ }^{\circ}$ of the Civil Code). 
Subrogation of the Guarantee Fund and liability of the persons failing to take out mandatory...

Against this new background, there was again case law making a similar claim ${ }^{21}$. Some scholarship also sustained that the new provision led to the conclusion of there being a right to bring an action on the mere grounds of failure to take out insurance ${ }^{22}$. The arguments put forth were of formal nature, referring to the fact of No. 3 expressly mentioning that the persons mentioned were solidarily liable before the Fund. Since the general rule is already solidary liability between those liable for damage to another (Art. $497^{\circ}$ of the Civil Code), if the persons referred to by Art. 54. ${ }^{\circ}$, No. 3, of the Act were only those liable before the victim, and the Fund was merely subrogating to the right of the victim, then it would be unnecessary to set out expressly the rule of solidarity. One had to conclude therefore that those answering before the Fund were not only those liable for the accident.

\section{Reappraisal of the arguments. The right of the Fund as a proper right to subrogate}

The interpretation just laid down does not express the prevailing opinion in case law, though. There are, indeed, compelling arguments against it. This section will present them, identifying the points made by the courts and supplementing them when necessary.

\section{Argument referring to the wording of Acts}

First of all, case law stresses that when one considers the provisions in their whole, they identify the addressees of the right of the Fund as those who were responsible for the accident. Before going through the wording of the provisions, its technical imperfections should be underscored, surfacing in redundancies and terms that seem to point to different constructions. However, all in all, the provisions seem to fit better the mentioned construction of the right.

In what regards both the former and the present Act, this is from the outset mirrored in the fact of the entitlement of the Fund being cut out as the right to subrogate in the position of the victim (see III.2).

21. Judgement of the Appellate Court of Porto, $27^{\text {th }}$ June 2018 (Rap. Rodrigues Pires), Proc. 634/11.8TBPNF.P1. The Court states that, under the provisions applicable, the owner of the vehicle is to respond before the Fund for the sole reason that he/she failed to take out insurance, even when there is no liability for the accident. However, the Court considers that the owner can be exonerated before the Fund if he proves that the vehicle was used abusively without his/her permission, since it would not be fair to make him/her answer in that case. This reasoning deserves straightforward criticism: if the owner is said to answer solely for not having complied with a duty to take out insurance and the fact that he was not liable for the accident is held as irrelevant, then there is no reason to exonerate him in those instances - in the end, the Court is forced to temper its strict departure point by a solution in equity, that simply has no support in the norms applicable and is therefore not legitimate. The judgement of Appellate Court of Lisbon, $18^{\text {th }}$ February 2014, also refers to the fact that the vehicle was not being used without authorization, which would be irrelevant to its clear stance on the grounds of the duty of the owner towards the Fund. See below, III. 4.

22. Oliveira, A. da Costa, Seguro obrigatório de responsabilidade civil automóvel, Síntese das alterações de 2007 (DL 291/2007, 21 Ago), Almedina, Coimbra, 2008, pp. 99-100. 
The former Act added more arguments to this point in that it set out in Article $25 .^{\circ}$, No. 3 , that those failing to comply with the duty to take out insurance that had had to compensate the Fund had then a right of recourse against other persons liable for the accident. From there one should infer that those compensating the fund should also have been liable for the accident ${ }^{23}$. According to case law, the purpose of the specific reference to those who were under the duty to take out insurance was to state clearly (albeit quite redundantly) that the Fund did not have to duty to bring an action against all the liable parties simultaneously. It could choose who it brought the action against ${ }^{24}$.

The new Act does not refer to those under the duty to take out insurance as addressees of the rights of the Fund. But it does refer separately to the holder, the owner and the driver, independently of the one under the duty to take out insurance (Art. 54. ${ }^{\circ}$, No. 3). Now, one would say that if the provision meant only the persons liable for the accident, it would refer only to the holder (s); if it refers to the owner, that must mean that he should respond for not having taken out insurance.

That would be, though, a very strong conclusion to extract from a poorly worded provision. If the owner was to answer on those grounds, then so should the usufructuary, the buyer in case of retention of title or the lessee in case of leasing; but none of them is mentioned by the norm. Furthermore, the reference to the driver would anyway need to be restrictively interpreted in order to limit it to the cases where the driver is liable for the accident. The driver will not be liable when he/she caused the accident without fault and while driving as an employee of another person, so there would be no ground to make him/her an addressee of the rights of the Fund in any case. Moreover, because the quality of driver does not in itself even imply the duty to take out insurance.

The provision of Art. 54. ${ }^{\circ}$, No. 3 cannot do without being corrected through interpretation. Its meaning should be brought together with No. 5 that, such as previous Art. $25^{\circ}{ }^{\circ}$, No. 3 , gives the person that paid the Fund a right of recourse against other persons liable for the accident.

One should also not place too much weight on the fact that the new provision explicitly sets out solidary liability between the mentioned persons. It is in fact a redundancy before the general rule of solidarity that applies when several persons are liable for the same damage. However, such a redundancy can simply serve purposes of clarification, especially when the persons involved may be under liabilities of different nature - strict or based on fault - that involve the application of different sets of norms. The Civil Code itself is "guilty" of redundancy in this matter, since it repeats for the particular case of liability for road traffic accidents the general rule of solidary liability that is set out for cases of joint liability for damage caused to another (Art. 507. ${ }^{\circ}$, No. 1 vis-à-vis Art. 497. ${ }^{\circ}$.

All this leads to the conclusion that the most reasonable interpretation is the one that limits the circle of addressees to those liable for the accident ${ }^{25}$.

23. Making this point, judgement of the Supreme Court of Justice, $2^{\text {nd }}$ March 2004 (Rap. Nuno Cameira); Appellate Court of Lisbon, $19^{\text {th }}$ March 2015 (Rap. Vitor Amaral), Proc. No. 9036-11.5T2SNT.L1-6, that thoroughly quotes the judgement of 2004 of the Supreme Court on this matter. The first judgement also considers that the provision setting out the cases in which the Fund can be brought to compensate the victims refers to the case where the person liable for the accident was not covered by liability insurance. However, this reference does not seem relevant: the lack of insurance covering the acts of those responsible for the accident is of course one of the grounds triggering the intervention of the Fund; but it has been explained that a whole different question is that of knowing who is under the duty to take out insurance.

24. Judgement of the Supreme Court of Justice, $2^{\text {nd }}$ March 2004 (Rap. Nuno Cameira);

25. The same conclusion is reached on the judgement of the Supreme Court of Justice, $8^{\text {th }}$ November 2018 (Rap. Abrantes Geraldes) and on the judgement of the Supreme Court of Justice, $6^{\text {th }}$ June 2019 (Rap. Pizarro Beleza), which, though, point mainly to the reference of the provision to the right of subrogation. 
Subrogation of the Guarantee Fund and liability of the persons failing to take out mandatory...

\section{The right of the Fund as a right to subrogate}

The wording of both the former and the present Act provides yet a very significant ground for construing the right of the Fund as only giving it a claim against those liable for the accident, by naming it as a right to subrogate to the rights of the victims. The mechanism of subrogation is not only the one referred to by the provisions laying down the right (Art. 25. ${ }^{\circ}$, No. 1 , former Act and Art. $54 .^{\circ}$ No. 1, present Act ], but is also the one referred to in the title of the norms.

In fact, in case of subrogation, the right exerted is the same that previously belonged to a former creditor $^{26}$. The claim based on subrogation is hence not equivalent to a claim based on the right of recourse. The right of recourse is conceived of as a new right, usually attributed in cases of solidary liability to the solidary debtor that was brought to pay more than his/her share to a common creditor. Such a right of recourse is tailored by the shares of liability belonging to each of the debtors and did not exist as such in the patrimony of the original creditor ${ }^{2 ?}$.

The construction of the right of the Fund as a right to subrogate to the right of the victim against those liable also suits the logic underlying the intervention of the Fund in those exact cases, where the persons liable were identified. In these cases, the Fund is definitively not supposed to bear the cost of compensation; his duty towards the victim is only a way of protecting him/her against potential insolvency of the ones who are responsible for the accident and should definitively bear its consequences ${ }^{28}$. The Fund acts as someone providing security to the victims, who is then subrogated to the rights of the former creditor in order to recover what he paid from those actually liable (for a parallel place, see IV. G. - 2:113, "Security provider's rights after performance" of the DCFR).

In this point No. 6 of Article $54 .{ }^{\circ}$ would stand out and question the conclusions presented above. Article $498 .^{\circ}$, No. $^{\circ} 2$ of the Civil Code, that it makes applicable to the right of the Fund, regulates the right of recourse between those liable in cases of joint liability. It sets out that that the period of prescription of the right is three years and begins with the compensation of the victim. This does not fit the construction of a subrogation, where the person subrogated to the right should receive it as it was, without any change in the period of prescription.

Nonetheless, one can also reason reversely, and consider that the fact of the lawmaker having to lay down a special provision for this matter (Art. 54. ${ }^{\circ}$, No. 6), means that there was only need to adapt the rules on a specific point, and that, apart from this aspect, the right of the Fund is the same that was held by the victim. As is typical of a contrario arguments, a pure formal reasoning does not prove decisive in this case, because the formal argument can be reversed. The reasoning has to be grounded on substantial arguments. And, whereas, as shall further be displayed,

26. This is mirrored in the definition of subrogation provided by the DCFR: "subrogation, in relation to rights, is the process by which a person who has made a payment or other performance to another person acquires by operation of law that person's rights against a third party".

27. This point is made in the judgement of the Supreme Court of Justice, $18^{\text {th }}$ January 2018 (Helder Roque), Proc. No. 126/10.2TBVPV.L1.S1; judgement of the Supreme Court of Justice, $8^{\text {th }}$ November 2018 (Rap. Abrantes Geraldes); judgement of the Supreme Court of Justice, $6^{\text {th }}$ June 2019 (Rap. Pizarro Beleza); similarly, judgement of the Supreme Court of Justice, 23 ${ }^{\text {rd }}$ May 2019 (Oliveira Abreu), Proc. No. 424/13.3T2AVR.P1.S1, though, for procedural reasons, the decision does not need to apply the norm to the facts.

28. F. Albuquerque Matos, "O Fundo...", cit., p. 563. 
there are strong substantial arguments not to give the right of the Fund a different extension of that of the right of the victim, there are no less strong arguments demanding the adaptation of the norms on prescription in its regard.

In fact, the right to compensation of the victims is subject to prescription in an exceptionally short period: three years, whereas the general rule on the Portuguese Civil Code is 20 years. Therefore, if the Fund was simply subject to the original period of prescription of the right to compensation, it would find itself with even less than that delay ${ }^{29}$ to enforce its rights against those liable for the accident. Moreover, it cannot be said that the extension of the delay would counter the legitimate expectations of the debtors, as would be the case in typical subrogation cases. In this case, the Fund and those supposedly liable for the accident were both defendants in the action for compensation brought by the victim. This is a case of necessary joinder of parties in the process established by law, as shall be described just below (III. 3). Therefore, since one agrees that the addresses of the right of the Fund are those that were exactly deemed liable by the same decision that determined the Fund should compensate the victim, the extension of the period during which its right can be enforced against them should not surprise them, but rather come as an effect of the decision of the Court.

In conclusion, the construction of this right under the mechanism of subrogation determines that it can only be exerted against those liable before the victim, i.e., those liable for the accident. In fact, the case law that conceives of a right of the Fund against the one who failed to take out insurance, but was not liable for the accident, conceives it as the right of recourse ${ }^{30}$. The courts do not give any reason for this, and it should be said that they all refer to the former Act, that did not give any argument for such a construction of the right.

The rights of the Fund against those who caused the insurance contract to be ineffective, as laid down in Article 54. ${ }^{\circ}$, No. 4, of the present Act cannot be construed, though, as rights of subrogation. Those persons would, indeed, not be under any duty to indemnify the victim of the accident. Still, this is a very special case, which, as shall be seen below (III. V), should, moreover, be interpreted restrictively. A whole different thing would be to say that the right set out by the provision was not, even in the typical cases where it is to be applied, the right of subrogation to existing rights, but the right of recourse. This formal argument could be overcome if there were compelling systematic arguments, proving that, on the whole of the provisions applicable, the right was regulated as the right of recourse, and that the policy and principles underlying the norms justified that solution. This is not, however, the case.

29. He would tend to have three years counting from the final court decision that awarded compensation to the victim, since bringing the claim before a court determines the interruption of the prescription period. A new prescription period will start to run with the final decision (Articles $326 .{ }^{\circ}$ and $327 .^{\circ}$ of the Civil Code).

30. Appellate Court of Coimbra, $25^{\text {th }}$ May 2004; Appellate Court of Porto, $26^{\text {th }}$ January 2009; judgement of the Appellate Court of Lisbon, $18^{\text {th }}$ February 2014. 
Subrogation of the Guarantee Fund and liability of the persons failing to take out mandatory...

\section{The right of subrogation as one of the grounds for setting out a case of necessary joinder of defendants in the action brought by the victim}

The appellate court of Guimarães presents an interesting argument in this regard ${ }^{31}$. As the Fund and those liable for the accident answer solidarily before the victim, the victim would normally have the choice to bring the action for compensation against one or some of them (or against their insurers] and would not be forced to bring the action against all of them. This is what happens in cases of joint liability for torts, where the tortfeasors are solidarily liable: it is up to the victim to choose against which of them to bring the action.

But that is not so when the victim brings the action against the Motor Guarantee Fund on the grounds that the person deemed liable, having been identified, was not covered by valid and effective insurance. In this case, the law sets out a case of necessary joinder of parties and determines that the action has to be brought against the person deemed to be liable and the Fund (Art. 29. ${ }^{\circ}$, No. 6, of the former Act, and Art. 62..$^{\circ}$, No. 1, of the present Act). This rule is explained through the existence of the right to subrogate belonging to the Fund. As has been said, it is not supposed to bear the cost of compensation definitively, but, much on the contrary, it is expected to recover it from those actually liable for the accident. The fact that they have to be defendants in the same action that convicts the Fund to pay is said to attend the purpose of establishing their liability for the accident trough a decision that the Fund can also avail itself of. This will serve its right of subrogation, since its addressees, being those liable for the accident, will have already been identified as such by a court decision.

The option of the lawmaker for a necessary joinder of the parties also allows the Fund to have access to the arguments and means of evidence that the person deemed liable presents to the court, even in what regards the establishment of its duty towards the victim. Nevertheless, the most important effect of that rule is to serve the right of subrogation of the Fund: since it will replace the victim in the right he/she would have against the person liable, it becomes especially relevant that the judicial establishment of that liability has binding effects towards the Fund.

\section{Scope of the norm setting out the duty to take out insurance and consequence of its infringement: incompatibility with the system of non-contractual liability, and with the criteria of distributive justice that it embodies}

If one abides by the construction of the right of the Fund as the right to subrogate, then there will be no ground to make the person that merely failed to take out insurance compensate the Fund for the sums paid to the victim. In order to grant the Fund such a compensation, one would have to place it a consequence of infringing the norm setting out the duty to take out insurance - besides, of course, overcoming the fact that the norms do refer expressly and foremost to subrogation.

That would imply that one framed that provision as a ground for non-contractual liability of the person under the duty towards the Fund, since they were not bound by any previous special relationship, vg., of contractual nature. The Portuguese system of non-contractual liability

31. Judgement of the appellate Court of Guimarães, $2^{\text {nd }}$ May 2019 (Amália Santos), Proc. No. 3128/15.9T8GMR.G1. 
bears a strong similarity with the German system, in that it relies on three grounds of liability: damage caused to the person or property of the victim, breach of statute intended to protect interests of the kind affected ["Schutzgesetz"], or exercise of a right in infringement of public policy and good practice (Art. $483 .^{\circ}$, No. 1, for the first two cases, and Art. 334. ${ }^{\circ}$ for the latter). In order to grant the Fund compensation for the amounts disbursed due to lack of insurance, the Article setting out the duty to contract would therefore have to qualify as a statute intended to protect the economic interests of the Fund.

A system of non-contractual liability such as the one described takes a very restrictive stance towards compensation of pure economic loss. The main reasons for that are well known: the purpose is to "keep the floodgates" of (non-contractual) liability shut, so as not to hamper economic life. The main principle is, accordingly, that there is only reparation of pure economic loss when there is an intentional or at least reckless conduct against public policy and good practice. There are, though, countless norms, by virtue of which infringement would be a plausible cause for economic losses experienced by third parties. Therefore, when the interests affected are purely economic, one should be cautious in identifying a norm as a statute intended to protect them, in order not to compromise the whole rationale and balance underlying the compensation of non-contractual damage ${ }^{32}$. This should not prevent this ground of liability from playing a useful role in the protection of individual interests in the context of market economy ${ }^{33}$. All in all, the recommended caution does not call for an excessively restrictive approach, but it does call for a careful grounding of the qualification of a statute as a "Schutzgesetz".

Such a task relies on interpreting the norm at stake, in order to determine whether it aims to protect individual interests, and interests of the specific kind offended; but there is no precise methodology that has yet deserved wide acceptance in that regard ${ }^{34}$. One could approach that task in a relatively linear way, resorting to literal and historical elements, since their formal and objective nature could provide a more direct answer.

A linear approach to the matter would show that the duty to take out insurance served the main purpose of protecting the victims of road traffic accidents, as has been time and time again underscored by the Directives in the matter and is clearly mirrored in the preamble to both the former and the present $\mathrm{Act}^{35}$. Due to the interference and role of the Fund, the infringement of that duty does

32. Canaris, C.-W., Schutzgesetze - Verkehrspflichten - Schutzpflichten, [in:] FS Larenz zum 80. Geburtstag, C. H. Beck, München, 1983, p. 58; Wagner, G., BGB § 823 Schadensersatzpflicht, [in:] MüKo BGB, C. H. Beck, München, 201?, retrieved at http://beck-online.beck.de (last accessed at 19.11.2019), No. 476 and 504; Monteiro, J. F. Sinde, Responsabilidade por conselhos, recomendações ou informações, Almedina, Coimbra, 1989, pp. 255-256; Frada, M. Carneiro da, Direito civil, Responsabilidade civil, 0 método do caso, Almedina, Coimbra, 2010, p. 75.

33. Wagner, G., BGB § 823, No. 476 and 504 and ff.

34. Hager, J. G. Die Verletzung eines Schutzgesetzes, § 823 Abs 2, [in:] Staudingers Kommentar BGB, §§ 823 E-I, 824, 825 (Unerlaubte Handlungen 1 - Teilband 2), Sellier - De Gruyter, Berlin, 2009, retrieved at https://www. juris.de (last accessed at 19.11.2019), G16 (and ff.). In what regards the methodology favored by Canaris, C.-W., Schutzgesetze, maxime pp. 75-76 and later by Larenz, K., Canaris, C.-W., Lehrbuch des Schuldrechts, II, Besonderer Teil, 2, C. H. Beck'sche, München, 1994, pp. 433 and ff. and favored in Portugal by Monteiro, J. F. Sinde, Responsabilidade..., pp. 254 and ff., see below.

35. In fact, the BGH has, with very similar arguments, qualified the norm setting out the duty to take out insurance as a "Schutzgesetz", as early as in 1961 BGH (Proc. VI ZR 121/60, $5^{\text {th }}$ December 1961, at https://www.prinz.law). Its conclusion relied exclusively in the fact that both the Preamble of the Act and the reports presented during the legislative procedure stated the purpose of protecting the victims of accidents. This conclusion was later 
not reflect entirely on the victim's position, who will be compensated by the Fund (though it does have consequences, since the victim will not receive as much from the Fund as they would form an insurer, and those liable may be insolvent ${ }^{36}$. The logical inference from what precedes would then be that the Fund, that, in absence of insurance, is forced to step in in order to protect the victim, is at least concurrently the holder of the interests that the provision at stake aims to protect.

Its infringement would grant them a right to compensation, under the second type of noncontractual liability.

However, such a linear approach is not persuasive. As it is not sufficient to attend to the norm at stake, since treating it as a ground for liability will have consequences for the whole system ${ }^{37}$. The logic underlying the system incorporates decisions in terms of balancing of interests and distributive justice, that such a solution should not compromise. The systematic elements of interpretation come, thus, to the fore.

"Keeping the floodgates shut" implies, first of all, that the wrongfulness of the conduct should be as severe as the one affecting the conducts deemed unlawful according to the other two grounds of liability. The importance of the interests harmed will bridge the analogy of the case with the first ground of liability (injury to person or property of another); the gravity of the reproach deserved by the conduct will bridge the analogy of the case with the third ground of liability (public policy and good practice) ${ }^{38}$.

Furthermore, requiring the seriousness of the infringement serves the purpose of transparency, alerting the potential wrongdoers to the fact that a certain action is strongly reproved and may attract heavy economic consequences ${ }^{39}$.

When looking at the specific question under scrutiny, it should be reminded that the damage caused to the Fund is a pure economic loss, therefore bearing no analogy to the interests centrally protected by non-contractual liability.

In what concerns the seriousness of reproach, it is of interest that under both the former and the present Act, infringement of the duty is sanctioned by administrative fines, and not by criminal penalties. That can be taken as an index signalling a lesser gravity of the offence; however, due to the present expansion both of criminal norms protecting the economic and financial system,

applied by OLG München (Proc. $10 \cup 1793 / 71,24^{\text {th }}$ March 1972, at www.juris.de), which did not add any new argument to its underpinnings, and is currently quoted as established case law (Wagner, G., BGB § 823, no. 526).

36. It is commonly accepted that the victim is allowed to accumulate the rights that the system of social security grants him/her with the right to obtain compensation from the tortfeasor (Pinto, P. Mota, Interesse contratual negativo e interesse contratual positivo, I, Coimbra Editora, Coimbra, 2008, pp. 801-802). When compensation is paid by the Fund, the victim's position is weakened, since the Fund will deduct the amounts paid by social security from the compensation it provides (Art. $51^{\circ}{ }^{\circ}$. No. 3, present Act).

37. Knöpfle, R., Zur Problematik der Beurteilung einer Norm als Schutzgesetz im Sinne des § 823 Abs. 2 BGB, „NJW”, 1967, n. ${ }^{\circ} 16$, pp. 699-700; Canaris, C.-W., Schutzgesetze..., pp. 47-48; Wagner, G., BGB § 823, No. 503; Monteiro, J. F. Sinde, Responsabilidade..., p. 252.

38. Knöpfle, R., Zur Problematik..., p. 700; approvingly, J. Sinde Monteiro, Responsabilidade ... cit., pp. 252-253.

39. Canaris, C.-W., Schutzgesetze..., p. 50. The argument of protection of expectations seems to underlie the conclusion that the criminal norm setting out perjury is a "Schutzgesetz", since oath would alert the witness to the seriousness of infringement, whereas the norms of the Civil Procedure Code setting out duties to answer truly to the questions posed by court do not have that status (see pp. 59-60 of the last op. cit.). 
and of administrative norms pursuing the same goal, and to the lack of a solid "pre statutory" criterion to identify which conducts deserve criminal sanctions and which ones deserve merely administrative sanctions, the value of this index should not be overstated ${ }^{40}$.

However, it does stand out that the duty to take out insurance is imposed to laypersons, and that it affects a very broad and diverse set of people, who may have different degrees of regular contact with the vehicles they use and may be very differently informed on their duties in connection with such use. Especially in what regards holders that do not use their vehicles regularly, or even at all, the degree of fault that characterizes their omission to take out insurance may be very low. In instances such as the one that gave rise to the preliminary ruling, it is patent that an owner that does not make use of the vehicle can be persuaded of not having to insure it; and, when courts themselves have doubts on the matter, it is questionable whether one should conclude that there was fault in that conduct.

A further factor entering the assessment is the balance of the interests of the victim and those of the wrongdoer, where the impact that answering for the damage would have for the latter should be particularly considered. In fact, the criterion of "practicability" that is sometimes mentioned seems rather to express this last concern. According to it, rights to compensation should be denied when they would attract massive litigation ${ }^{41}$. The issue of massive litigation as a burden to the adjudication system does not seem, however, to be a decisive source of a concern in the context of the current legislative efforts, both at a country level and at a EU level, to make agents overcome their rational apathy, and bring them to claim their rights through class litigation. The most striking problem brought by this massive litigation would be the burden that it would place on the wrongdoer himself/herself.

The importance of this balancing of the impact of owing/receiving compensation for the potential wrongdoer and for the potential victim should not be minimized. In particular, the effects of the duty to compensate upon the wrongdoers should not be discarded as irrelevant. They are a matter of distributive justice and of the balance intended by the system for the distribution of harmful consequences.

Now, it should be held present that the extension of the right to compensation of the victims of road traffic accidents is determined according to the provisions on liability for fault and on strict liability. These provisions determine which of certain harmful consequences should be borne by a person different from the one directly affected; and they do, by bringing their own standards to assess which of those consequences should be attributed to the person liable.

40. On this lack of a genuine material distinction between the two kinds of unlawfulness, that could precede the decision of the lawmaker, already decades ago, Jescheck, H.-H., Das deutsche Wirtschaftsstrafrecht, „JZ”, n. ${ }^{0} 15-16,1959$, pp. 460 and ff. One has to agree, thus, with, Wagner, G., BGB § 823, No. 47?, when the author relativizes the criterion proposed by Canaris, C.-W., Schutzgesetze..., maxime pp. 75-76, who sustained that, although other factors should be taken into account, the criminal or administrative nature of the norm infringed would weigh decisively: in the first case, one should start from the presumption that it was a "Schutzgesetz", whereas in the latter one should presume that it did not give rise to compensation. Taking the criminal nature of the norm as mere index for qualification, Hager, J. G. Die Verletzung..., G6.

41. Knöpfle, R., Zur Problematik..., p. 700. 
Subrogation of the Guarantee Fund and liability of the persons failing to take out mandatory...

That is striking in what regards liability for fault, where the degree of fault is, in cases of mere negligence, one of the factors to ponder in order to establish the amount of compensation (Art. $494 .^{\circ}$ Civil Code); and it can even arguably interfere with the establishment of causation.

And it is also striking in what concerns strict liability, where the criterion of unlawfulness is replaced by the criterion of connection with the source of risk set out by the norm. No-fault liability rests upon the decision of the lawmaker to remove in a specific case the damage from where it occurred and make someone else that did not cause it through misconduct answer for it. This rests typically in the idea that the one who controls a certain source of risk and benefits from his/her position, should compensate third parties for the disadvantages that this causes them to suffer. That demands, first of all, that the damage to be compensated maintains a tight connection with the source of the risk; only then can that transferal of the disadvantageous consequences be justified.

The duty infringed by the person failing to take out insurance does not rely in the same underpinnings as the duties of care in road traffic, or as the norms on strict liability in the same context. If he/she had to bear the consequences of liability, the extension of his/her duty to indemnify would then be determined by another set of values and interests. He/she would not have any possibility of control or mitigation of the extension of his/her duty to indemnify, since he/she is not the source of the conduct, or of the risk causing the accident. This runs contrary to the purpose of the norms on road traffic liability, considering the allocation of harmful consequences that underlies them. There would have to be compelling arguments in terms of distributive justice to justify such a result. As shall be seen below, that is not the case.

This is what seems to be implied by case law, when it states that making the person who failed to take out insurance answer for the consequences of the accident would amount to a derogation of the norms on strict liability for the use of vehicles (Art. 503. ${ }^{\circ}$ of the Civil Code) ${ }^{42}$. However, the courts do not clarify why they think that such an interference with the norms on strict liability is not justified by the unlawfulness of failing to take out insurance.

In fact, such a result does not seem acceptable when one thinks furthermore that the issue is not even that of determining whether the damage should lie with the victim or be borne by the person obliged to insure. The issue is to determine whether the damage should be borne by the collectivity, through the Guarantee Fund, or whether it should fall entirely upon the person that did not take out insurance. In practically all the range of damage caused by motor vehicles - apart from cases of severe misconduct of the person liable, where the insurer has the right of recourse regarding the amounts paid - the lawmakers have made a clear decision as to impose that such harmful consequences should not fall entirely upon the person liable, but should be dispersed through the mechanism of insurance.

This last reasoning would raise two objections.

It would be said, firstly, that the system is intended for the protection of the victims, and not of those liable. It cannot be denied, of course, that the main concern of the system is especially to remove the damage from where it is unfair that it lies, since it was caused by a reproachable action of another person. However, as has been discussed over the past decades, technology has brought about a considerable number of activities which pose significant risks to third parties, but

42. Judgement of the Supreme Court of $2^{\text {nd }}$ March 2004 (Rap. Nuno Cameira); judgement of the Appellate Court of Lisbon, of $19^{\text {th }}$ March 2015 (Rap. Vítor Amaral); judgement of the Supreme Court of $18^{\text {th }}$ January 2018 (Helder Roque). 
are simultaneously considered generally beneficial to the collectivity ${ }^{43}$. This is the realm of damage caused by accidents, which are often brought about either without fault or with very low degrees of fault. The scope of the systems of compensation of that damage is open not only for the protection of the victims, but also the promotion of the activities themselves by protecting those conducting them, since it would be undesirable that fear of liability would deter from their practice.

The person failing to take out insurance is, of course, not liable for the accident. Nonetheless, the preceding remarks do concern him/her, since they stress the fact that the system is built around the idea that, except in cases of very severe misconduct, the damage should not be borne by one person alone. This would point to the intervention of the Guarantee Fund, which, in its public nature and funding, is the cornerstone of the system of socialization of damage caused by road traffic accidents ${ }^{44}$.

The second objection would refer to the fact that the person that failed to take out insurance failed exactly to perform his/her role to keep the whole system functioning, since he/she failed to enter into the contract and pay the premia necessary to finance coverage. However, this remark begs the question, since it relies on the assumption that the duty to take out insurance (and pay the premia] would rest unsanctioned if it were not for the duty to reimburse the Fund.

That is in fact not true. Failure to comply with the duty to take out insurance is sanctioned by administrative fines, whose amount is set according to the circumstances, varying within a certain range. This allows for taking into account the degree of fault of the person obliged, instead of being simply blind to the reproach they deserve. Furthermore, the law sets a maximum fine applicable, in terms commensurate with the seriousness of the offense. This does not bring the risk of insolvency that is typically associated with bearing the cost of bodily damage caused to the victim of the accident.

These remarks lead, in fact, to the last argument: that of the disproportionality of such a duty to compensate imposed upon the infringing party, when compared to his/her wrongdoing or degree of fault. The same omission of a person under this duty may, independently of his/her degree of fault, make him/her liable from a compensation of a small or great amount. This is all the more striking in cases where a small carelessness of a layperson that did not take out the contract would bring about his ruin.

Accordingly, as the decision on the case of the preliminary ruling states, the systematic inadequacy of this solution has been noticed in the cases where the owner is not liable for the accident because the vehicle had been taken without their consent. In these cases, it would be most shocking to impose on him/her a duty to indemnify the Fund, because the owner has generally already

43. Oliphant, K., Landmarks of no-fault in the common law, [in:] Shifts in compensation between private and public systems, Boom, W. H. v., Faure, M., [ed.], Springer, Wien/NewYork, 2007, passim; Knetsch, J., Le droit de la responsabilité et les fonds d'indemnisation, Analyse en droits français et allemand, L. G. D. J., Paris, 2013, pp. 19-54; on the effect of both habit and stress on the drivers, making negligence a frequent phenomenon, Caemmerer, E. v., Das Verschuldensprinzip in rechtsvergleichender Sicht, „RabelsZ”, 1, 1978, p. 20.

44. On the patent social mission of the Automobile Guarantee Fund, Matos, F. de Albuquerque, 0 Fundo..., pp. 564 and ff.; this social role becomes more prominent when it implies the very dispensing with the establishment of civil liability, as happens when the person responsible for the accident has not been identified (generally, see Knetsch, J., Le droit..., pp. 146 and ff.]. 
Subrogation of the Guarantee Fund and liability of the persons failing to take out mandatory...

suffered a damage in his/her property and would have furthermore to stand up for an indemnification that can very easily make him/her insolvent ${ }^{45}$.

As a consequence, the case law that favours the sterner interpretation - liability before the Fund independently of liability for the accident - ends up by singling out the question of the vehicle having been illegitimately used or not and by considering that this fact can, by itself, exclude the liability before the Fund. This solution is, though, incoherent with the very departure point of this case law and has absolutely no legal ground ${ }^{46}$. When one considers that the only ground for the duty to compensate the Fund is lack of compliance with the duty to take out insurance, then the fact that the person under that duty, besides not being liable for the accident, was himself/herself victim of a wrongdoing should be totally irrelevant.

In what regards the means of reaction to an infringement, administrative fines are therefore the legitimate mean. Their reactive effect should be supplemented by preventive measures, that allow the inspection and control of compliance before any accident occurs. More measures of this kind are expected with the new Motor Insurance Directive, which is currently under appreciation of the European Parliament.

\section{The instances of subsidiary liability and the case for a restrictive interpretation}

Finally, attention should be drawn to the norm that determines that those who have contributed to the mistake or defect causing the contract to be absolutely or relatively null, as well as the seller of the vehicle that did not comply with the formalities regarding motor insurance, are subsidiarily responsible towards the Fund (Art. 54. ${ }^{\circ}$, No. 4, of the present Act). This norm was introduced by the present Act and is arguably a questionable option of the Portuguese lawmaker. As said before, the duties set out by this provision go beyond the right to subrogate under scrutiny. They cannot be directly invoked to challenge the nature of such right, but they could be invoked as instances of an overriding purpose of protection of the Fund.

Such an overriding purpose would from the outset not seem sound in terms of principle. Nonetheless, at least the first part of the norm still seems to rely on the purpose of socialization of the damage.

The first part of the norm regards those who caused the insurance contract to be defective. Although the provision would seem to refer to an indeterminate circle of persons, scholarship limits it to the persons that have professional duties of care in what concerns the conclusion

45. The inequity of the solution becomes especially vivid under the light of the facts analysed by the Supreme Court on $18^{\text {th }}$ January 2018, where the lack of insurance was due to the fact that the vehicle was kept in a garage while waiting a repair that was necessary for it to be approved at the mandatory vehicle inspection. In fact, under the former Motor Insurance Act (Article 36. ${ }^{\circ}$ ), although the insurance company could accept to insure a non-inspected vehicle, it had the duty to communicate the lack of inspection to the authorities, who would then impose fines on the owner of the vehicle. Under the present Act (Articles 17. ${ }^{\circ}$ and 27., No. 1, i)], although that duty of communication is no longer set out, it would be very unlikely that the insurer would accept to insure the vehicle with no inspection certificate, since that would make it lose its right to recover the amounts paid for an accident caused by malfunctioning of the vehicle.

46. The lack of logical soundness of this point is also underscored in the judgement of the Supreme Court of $2^{\text {nd }}$ March 2004 (Rap. Nuno Cameira). 
of the insurance contract ${ }^{47}$. These are the insurance mediators, who are, especially after the new Insurance Distribution Directive, under particularly demanding duties towards the policyholders in their process of entering into the contract ${ }^{48}$. As professional parties, mediators are under high standards of care, and should respond more broadly for want of it.

However, their duties are towards the policyholders, and not towards the Fund. One could appeal to the construction that extends duties of care towards third parties that will be directly affected by performance of the contract. But that would need further grounding, since the third party typically affected by a liability insurance contract would be the victim, and not the Fund.

In fact, by setting out of this case of liability, the lawmaker seems to have relied on considerations of broad socialization of damage and distributive justice, since insurance mediators have to take out mandatory civil liability insurance to cover damage caused through breach of their professional duties. This demand was introduced in 2006, just before the present Act; and may have been in the spirit of the legislator when it extended liability towards the Fund.

In this case, it will typically be the mediator's insurer to bear the consequences. Therefore, the damage does not have to be borne by a single person but is instead collectivized.

The same cannot be said in what regards liability of the seller of the vehicle that did not comply with the formalities regarding motor insurance, that does not have such a specific legal setting and is not accompanied by duty to take out liability insurance. In view of all that has been previously said, the solution laid down by this part of the provision seems highly questionable in terms of compatibility with the system of non-contractual civil liability. The provision has not deserved much attention so far, but one can expect it to be construed very restrictively. Anyway, it refers to a very specific set of cases, that do not seem to constitute a reason enough to question the general arguments.

\section{Conclusions}

The prevailing opinion of Portuguese courts deserves endorsement. Only those who not only failed to take out insurance but who were also liable for the accident should be held responsible towards the Fund ${ }^{49}$.

Holding them responsible before the Fund regardless of liability for the accident would not be entirely coherent with the wording of the applicable provisions. Specifically, it would not fit the construction of the right of the Fund as a right to subrogate to the right of the victim, since the victim does not have a claim towards those failing to take out insurance. The statutory reference to this right as a right to subrogate seems furthermore consistent with the fact that the law sets out a necessary joinder of parties, forcing the victim to present the claim against the Fund and those deemed liable for the accident. This assures that the Fund can enforce the same decision

47. Referring to those cases, Oliveira, A. da Costa, Seguro obrigatório..., p. 100.

48. The category of insurance distributors also encompasses insurers. However, when insurers themselves have caused the contract to be affected by a ground on invalidity, it does not seem that they can then refuse to cover. That would be barred by the prohibition of venire contra factum proprium.

49. The arguments laid out can also be useful in analyzing Art. $51 .{ }^{\circ}$, No. 4 , of the present Act, that poses questions similar to those handled here. 
Subrogation of the Guarantee Fund and liability of the persons failing to take out mandatory...

that upheld the rights of the victim against those from whom it can claim redress - that is, the persons liable for the accident.

In order to sustain that the Fund had the right to recover the amounts paid from the person who had not taken out insurance, one would have to see the provision setting out this duty as a "Schutzgesetz" protecting the Fund. That would amount to granting it protection against a pure economic loss, which can only take place when it proves consistent with the whole system of non-contractual liability.

That is not the case, since it would lead to results that challenge the general balance of the system, and the criteria of distributive justice that it embodies.

In fact, it would counter the underpinnings of the norms setting out either fault liability or strict liability for road traffic accidents, since the person that merely did not take out insurance without being liable for the accident will have had no control over neither the conduct nor the risks that caused it. It would furthermore amount to imposing a disproportionate sanction on the obligee. Due to the fact that accidents often entail bodily damage, the amounts of compensation can be high and cause the financial ruin of the non-insured person who should bear them. Moreover, those amounts are determined irrespective of the degree of fault in non-compliance with the duty to buy coverage.

The favoured solution that limits the addressees of the right to those liable for the accident, does not imply simply letting the victim bear the damage. It amounts to letting the damage lie with the Fund, thus socializing its impact. This solution is also not likely to incentivize breach of the duty to take out insurance. Non-compliant parties suffer administrative fines, that are fittingly able to take into account the degree of fault in non-compliance. This way of enforcement is, moreover, supplemented by preventive controls and inspections, whose scope shall predictably be extended by the new Motor Insurance Directive.

\section{Bibliography}

Alarcão, R. de, Ribeiro, J. de Sousa, Monteiro, J. F. Sinde, Sá, Almeno de, Proença, J. C. Brandão, Direito das obrigações, s. ed., Coimbra, 1983

Caemmerer, E. v., Das Verschuldensprinzip in rechtsvergleichender Sicht, „RabelsZ”, 1, 1978

Canaris, C.-W., Schutzgesetze - Verkehrspflichten - Schutzpflichten, [in:] FS Larenz zum 80. Geburtstag, C. H. Beck, München, 1983

Costa, M. J. de Almeida, Direito das obrigações, Almedina, Coimbra, 2009

Frada, M. Carneiro da, Direito civil, Responsabilidade civil, 0 método do caso, Almedina, Coimbra, 2010 Hager, J. G., Die Verletzung eines Schutzgesetzes, § 823 Abs 2, [in:] Staudingers Kommentar BGB, $\S \S 823$ E-I, 824, 825 (Unerlaubte Handlungen 1 - Teilband 2), Sellier - De Gruyter, Berlin, 2009, retrieved at https://www.juris.de (last accessed at 19.11.2019)

Jescheck, H.-H., Das deutsche Wirtschaftsstrafrecht, „JZ”, n. ${ }^{0}$ 15-16, 1959

Knetsch, J., Le droit de la responsabilité et les fonds d'indemnisation, Analyse en droits français et allemand, L. G. D. J., Paris, 2013

Knöpfle, R., Zur Problematik der Beurteilung einer Norm als Schutzgesetz im Sinne des § 823 Abs. 2 BGB, „NJW”, 1967, n. ${ }^{\circ} 16$

Larenz, K., Canaris, C.-W., Lehrbuch des Schuldrechts, II, Besonderer Teil, 2, C. H. Beck'sche, München, 1994 
Matos, F. de Albuquerque, Os proprietários e condutores de veículos à luz do binómio direcção efectiva e interesse próprio (Anotação), „Cadernos de Direito Privado”, 2014, n. ${ }^{\circ} 47$

Matos, F. de Albuquerque, 0 Fundo de Garantia Automóvel, Um organismo com uma vocação eminentemente social, [in:] Estudos dedicados ao Professor Doutor Luís Alberto de Carvalho Fernandes, I, Universidade Católica Editora, Lisboa, 2011

Monteiro, J. F. Sinde, Responsabilidade por conselhos, recomendações ou informações, Almedina, Coimbra, 1989

Oliphant, K., Landmarks of no-fault in the common law, [in:] Shifts in compensation between private and public systems, Boom, W. H. v., Faure, M., [ed.], Springer, Wien/NewYork, 2007

Oliveira, A. da Costa, Seguro obrigatório de responsabilidade civil automóvel, Síntese das alterações de 2007 (DL 291/2007, 21 Ago), Almedina, Coimbra, 2008

Pinto, P. Mota, Interesse contratual negativo e interesse contratual positivo, I, Coimbra Editora, Coimbra, 2008

Silva, J. Calvão da, Acordão do Supremo Tribunal de Justiça de 13 de Fevereiro de 2003, Anotação, „RLJ”, 2001, n. ${ }^{\circ} 3922$

Varela, J. de M. Antunes, Das obrigações em geral, I, Almedina, Coimbra, 2000

Wagner, G., BGB § 823 Schadensersatzpflicht, [in:] MüKo BGB, C. H. Beck, München, 2017, retrieved at http://beck-online.beck.de (last accessed at 19.11.2019)

\section{Subrogacja Funduszu Gwarancyjnego i odpowiedzialność osób, które nie wykupiły ubezpieczenia obowiązkowego: potwierdzenie przeważającej opinii sądów portugalskich}

W artykule omówiono problem subrogacji Funduszu Gwarancyjnego, w szczególności w sytuacji, gdy podmiot, który nie zawarł umowy ubezpieczenia odpowiedzialności cywilnej posiadaczy pojazdów mechanicznych, nie ponosi odpowiedzialności za wypadek. Autor prezentuje aktualne tendencje sqdów portugalskich, a także rozważa czy Funduszowi Gwarancyjnemu przysługuje roszczenie regresowe.

Słowa kluczowe: subrogacja, Fundusz Gwarancyjny, ubezpieczenie odpowiedzialności cywilnej posiadaczy pojazdów mechanicznych

MARIA INEES DE OLIVEIRA MARTINS - Faculty of Law of the University of Coimbra e-mail: mivom@fd.uc.p 